\title{
Economic Thought, Foundational Problems of Mainstream Economics and the Alternative of Islamic Economics
}

\author{
Jasmin Omercic \\ International Islamic University Malaysia, Malaysia \\ Corresponding email: omercic_jasmin@hotmail.com \\ Mohamed Aslam Mohamed Haneef \\ International Islamic University Malaysia, Malaysia, mdaslam@iium.edu.my \\ Mustafa Omar Mohammed \\ International Islamic University Malaysia, Malaysia, mustafa@iium.edu.my \\ Article History \\ Received: June $16^{\text {th }}, 2020$ \\ Revised: July $18^{\text {th }}, 2020$ \\ Accepted: July $20^{\text {th }}, 2020$
}

\begin{abstract}
Economic thought always permeated human living. Economic thought and the development of economics as a discipline in the last few centuries made it central to the world order. However, the foundational problems that mainstream economics suffers from led to uncounted crises and issues within the same order that created it. A physicalist ontology, rationalist epistemology, axiological futility and methodological deficiency are the problems of philosophical foundations of mainstream economics we reviewed in this paper. The methodology of this paper is qualitative and generally adopts the library research and critical content analysis methods to review and respond to identified foundational problems. Muslims is/ah and tajdid responses to the West and mainstream economics problems and issues found shape in Islamisation of Knowledge (IOK) and Islamic Economics (IE). The recent shift to Integration of Knowledge (IoK) universalizes the appeal and revives the zeal for IE development in light of loK based on IOK in this paper. A thorough analysis of IOK, IOK and IE responses to the West and mainstream economics enabled us to appraise it as the alternative and solution to the foundational problems. The paper clarified the way for future research in IE in light of IoK and directed the practitioners and regulators towards economic reasoning based on robust foundations.
\end{abstract}

Keywords: Alternative Foundations, Integration of Knowledge, Islamic Economics, Mainstream Economics.

JEL Classification : B40, B50, B59, P40

@ IJIEF 2020 published by Universitas Muhammadiyah Yogyakarta, Indonesia All rights reserved

DOI:

https://doi.org/10.18196/ijief.3226
Web:

https://journal.umy.ac.id/index.php/ijief/article/view/9101

\section{Citation:}

Omercic, J., Haneef, M. A. M., \& Omar, M. M. (2020). Economic Thought, Foundational Problems of Mainstream Economics and the Alternative of Islamic Economics. International Journal of Islamic Economics and Finance (IJIEF), 3(2), 171-198. DOI: https://doi.org/10.18196/ijief.3226 
Omercic, Haneef, \& Omar $\mid$ Economic Thought, Foundational Problems of Mainstream Economics and the Alternative of Islamic Economics

\section{Introduction}

\subsection{Background}

Economic thought has always come hand-in-hand with social development. A robust economy facilitated the prosperity and expansion of the Hellenic and Roman civilisations. It was present with the rise of Islam in the $7^{\text {th }}$ century which heralded sustained economic integration and established clear rights and duties, while also driving industrial Europe and the contemporary period (Chapra, 2016; Koehler, 2014). Modern economic thought took concrete shape in the last 300 years although its roots are traceable to the legacies of earlier civilisations. Medieval Thomistic (named by Thomas Aquinas 12251274AC), feudalist, mercantilist and protestant economic thought challenged the Christian Paternalistic Ethic $(\mathrm{CPE})^{1}$ and dichotomised economic thought into normative and positive trends. The later became dominant with the rise of science and the positivistic shift ${ }^{2}$ in economic thought that guided classical economics and continues to guide mainstream neoclassical economics today (Hunt, 2016; Blaug, 1997; Mahomedy, 2016, 2017).

Modern economics, like all other social sciences, are Western sciences, and rooted in foundations that reflect Western thought, worldview, and practice. Western civilisation and its worldview have asserted global influence since the $16^{\text {th }}$ century (Hunt, 2016; Al-Attas, 1978; Ali, 2016). Western economic thought is an undertaking of many scholars who spent their lives contributing to the field, primarily focusing on issues of growth and development. People's welfare and wellbeing receive little attention and the outcome of all these three centuries of economic thought is massive inequality and concentration of market/economic power as a hallmark of Western economics. It has perpetuated global crises and failed to reduce socioeconomic challenges in contemporary times according to Stiglitz (2019) and Furqani (2012). Many scholars have pointed out that its shortcoming is due to its materialist nature, the neglect of its foundations, ethical roots, and its spiritual/religious teachings. Such a materialist orientation of economics as a discipline may be the legacy of the Western civilisation but need not be the path taken by humanity at large (Mirakhor, 2020; Lee \& Lavoie, 2013; Putnam \& Walsh, 2012; Chapra, 2016).

For that reason, as the motivation of this paper, we appraise the development of Islamic economics (IE) in light of the Integration of

\footnotetext{
${ }^{1}$ Christian Paternalistic Ethic represented the authoritative status of some set of rules, regulations and foremost authority of the Catholic Church that determined what was ethical and moral in a society based on some scriptural and own interpretation (Hunt, 2016).

${ }^{2}$ Positivistic shift refers to greater use of mathematics, statistics, and physics in economics during the middle of the $19^{\text {th }}$ and early $20^{\text {th }}$ century to prove it is pure science and not social science (Arif, 1985, 1987).
} 
Omercic, Haneef, \& Omar $\mid$ Economic Thought, Foundational Problems of Mainstream Economics and the Alternative of Islamic Economics

Knowledge (IOK) based on the Islamisation of Knowledge (IOK) as an alternative to mainstream economics. By mainstream economics, we refer to the dominant neoclassical economics and elements of other streams of economics like Keynesianism, post-Keynesianism, Monetarism, etc., that are partially and indirectly acceptable within neoclassical economics (see Lee \& Lavoie, 2013 for more details).

Beginning with a brief evolution of the development of mainstream economics, this paper identifies its foundational problems that have caused many contemporary theoretical and practical problems globally. However, we acknowledge in this paper the strengths of mainstream economics, its beneficial contributions yet appraise the alternative IE in light of IoK based on IOK. Following gaps in literature corroborate this paper's motivation further.

Economics has proved to be neither value-free nor ideology-free in view of Canterbery (1987) and Hunt (2016). Religions (Islam, Christianity, or others) have contributed to its development. While the Islamic civilisation's contributions to economic thought are increasingly immanent in contemporary times, Western economists erroneously categorised it within the Schumpeterian gap ${ }^{3}$ according to Pribram (1983), Hunt (2016) and Islahi $(2005,2014)$. The rise of IE and IOK in the $20^{\text {th }}$ century proved that the Islamic civilisation contributed to the development of economic thought and other disciplines. With increased research, contemporary Western literature is being forced to acknowledge and revise the historical development of economic and other thought in view of Saliba (2007). That represents the need and corroborates this paper's aspiration to appraise IE development through loK based on IOK in order to revive the legacy/classical practices in contemporary times and overcome the problems and recurrent issues of mainstream economics.

From Canterbery (1987) and Hunt (2016), we learn that when mainstream economics mechanised the homo economicus in attempts to replicate scientific rationality axioms, its empiricism, predictability, infallibility, utilitarianism, consistency, constant maximisation of value levelled human activity into cause-effect relationships. The Great Depression in the 1930s witnessed Keynesian economics challenge such an approach to economics and promoted socialist economics packaged in the US President Roosevelt's 'New Deal' economic recovery programme, i.e. the greater role of government in markets and the rise of syndicate rights. The classical and

\footnotetext{
${ }^{3}$ This period known as the 'Schumpeterian Gap' lasted for over more than 600 years ( $7^{\text {th }}$ to $13^{\text {th }}$ century) to which the least credit is acknowledged for the development of economics as a discipline or science besides other sciences (Hunt, 2016; Ali \& Thompson, 1999). Today, it is gradually recognized and acknowledged.
} 
Omercic, Haneef, \& Omar $\mid$ Economic Thought, Foundational Problems of Mainstream Economics and the Alternative of Islamic Economics

other economic thought variants constantly rivalled it but ultimately all fell into the 'positivistic shift' trap. Therefore, this gap corroborates the need for an alternative approach to economics, like IE, that is aware of this trap and can integrate the best contributions of economic thought for betterment of humanity.

Moreover, modern economic thought proved to have questionable philosophical foundations that comprise its ontology, epistemology, axiology, and methodology. The positivistic-scientific quest in economics resulted in repetitive crises, irrational exuberance for stability and prosperity, financialisaton, environmental destruction, and constant materialisation and desacralisation according to Shiller (2015), Stiglitz (2019) and Al-Attas (2014). Hence, among the multiple assumptions, regressions, testing, modelling, and other economic methodologies, some are more and some less relevant today. Thus, the state of economics today suffers from a methodological deficiency resulting from marginalisation and narrow philosophical foundations, namely ontology (theory of being), epistemology (theory of knowledge and its sources) and axiology (the study of the nature of value or valuation) in view of Mahomedy (2016, 2017), Furqani (2012) and is evident from even Stiglitz (2019). ${ }^{4}$ Mainstream economics narrowed the nature, role, and position of human beings to that of homo economicus and a unidimensional or unidisciplinary positivistic development of economics. While some alternative Western economic schools or heterodox economic thought like post-Keynesianism, institutionalism, neo-Austrianism, neoRicardian or post-autistic economics and others questioned the approach and aspects of mainstream economics (Boşca, 2015), no one seriously questioned or discussed its philosophical foundations according to Mahomedy (2016) and Furqani (2012). This represents a great gap that this paper aims to fill.

Hence, while appreciating the beneficial contributions of mainstream economics, this paper attempts to address the identified gaps of foundational problems of mainstream economics, recurrent issues and general approach to economics as findings and results by highlighting Muslim responses to mainstream economics based on foundations that have the potential to overcome its identified foundational problems and issues. Since the encounter with Western civilisation and economic thought, Muslims objected to its approach and imposition of its narrow and flawed foundations and worldview. It is for those reasons that this paper appraises IE as an alternative in light of the contemporary significance and shift to loK yet based on IOK. We simultaneously acknowledge the need to overcome the

\footnotetext{
${ }^{4}$ See also Haneef (2014), Furqani and Haneef (2012), Hunt (2016), and Canterbery (1987) for greater detail.
} 
Omercic, Haneef, \& Omar $\mid$ Economic Thought, Foundational Problems of Mainstream Economics and the Alternative of Islamic Economics

shortcomings of IE and IOK raised since inception that in no way diminish their robust foundations. Many studies increasingly proved that IE and IOK proved to have sound and comprehensive philosophical foundations. For instance, such an approach is genuine and realistic in contrast to the abstract nature of mainstream Western economics in view of Haneef (1997) and Furqani (2012). The increasing significance of knowledge integration in contemporary times and the shift from Islamisation of Knowledge (IOK) to Integration of Knowledge (IOK) makes the development of IE with the use of beneficial contributions of mainstream economics conducive and commendable. This represents the way how this paper fills the gaps of questionable mainstream economics foundations, economic thought, its issues and constant economic instabilities as a major contribution of this paper to the reviving interest of IE development due to its potential in theory and practice. Linking the theoretical foundations of IE that we appraise as the solution to those of mainstream economics with the practices in the Islamic banking and finance industry has the potential to rectify recurrent challenges of the industry in actualising its aspirations genuinely. To justify that, later sections provide us with a greater insight into or review of the foundational problems of mainstream economics and acquaints us with the deeper repercussions of those foundations and related problems and issues.

\subsection{Objective}

With a clarified motivation of this paper to address the earlier identified gaps of mainstream economics' foundational problems, issues and general approach to economics, we can clearly state that the main objectives of this paper are to review the foundational problems of mainstream economics in greater fashion and then appraise IE development through IoK based on IOK through identification of Muslim responses to such economic reasoning and lifestyle since the $16^{\text {th }}$ century gradual western revival. Such objectives reveal the seriousness of the need for robust philosophical foundations that mainstream economics suffers from and credits Muslim responses to such foundations before they matured in many consequential issues prevalent in our times. Thus, it strongly supports our objective of appraising IE via IoK to produce an economics that meets the needs of humanity more appropriately.

Along the background and objectives in our introductory part of this paper, the following literature review section highlights in greater detail the problems, issues and approach of mainstream economics that further clarify the seriousness of the gaps that this paper aims to fill via appraisal of IE development via IoK based on IOK. We discussed the problems of physicalist 
Omercic, Haneef, \& Omar $\mid$ Economic Thought, Foundational Problems of Mainstream Economics and the Alternative of Islamic Economics

ontology, rationalist epistemology, axiological futility and methodological deficiency of mainstream economics. Those justify why IE development is possible and necessary. A section on the adopted methodology of this paper precedes the results and analysis section where we present the Muslim responses to western thought and that of economics generally through is/ah (reform) and tajdid (renewal) movements with a focus on IOK and IE. We finalised this section with explaining the significance of IE development via IoK based on IOK as the alternative approach to economic reasoning and foremost the solution to problems and issues of mainstream economics. Lastly, we conclude and provide recommendations for practitioners, regulators and future research.

\section{Literature Review}

This section reviews necessary literature in order to enable us to appraise in this paper the development of Islamic Economics (IE) in light of the Integration of Knowledge (IOK) based on Islamisation of Knowledge (IOK) as the solution to foundational problems and related issues of mainstream economics. It firstly presents the ontological, epistemological, axiological, and methodological foundational problems and related issues of mainstream economics. It then highlights the findings and results as Muslim responses in the form of islah and tajdid movements of which IOK and IE are relevant in overcoming the problems of mainstream economics. Despite their shortcomings, IOK and IE have sound foundations and decades of development have helped to identify the need and rising significance of IOK as the future framework approach of IE development that has the potential to overcome the problems of mainstream economics. Thus, addressing the mainstream foundational problems and adopting the IOK approach to developing IE is an alternative approach and has the potential to fill the gaps identified in sections that follow. That shall pave the way forward for IE methodological development with robust foundations. 
Omercic, Haneef, \& Omar $\mid$ Economic Thought, Foundational Problems of Mainstream Economics and the Alternative of Islamic Economics

\subsection{Problems and Issues with Mainstream Economics}

\subsubsection{Physicalist Ontology ${ }^{5}$}

Ontology is the branch of metaphysics that deals with the nature of being (Merriam-Webster, 2004). Mainstream economics adopted a 'physicalist ontology' as part of its philosophical foundations that perceives everything as physical because of the positivistic influence since the $16^{\text {th }}$-century that phased away the mercantilist phase of economic thought. The climax of physicalist ontology occurred in the middle of the $19^{\text {th }}$ century when it became the norm in science and life. ${ }^{6}$ Heilbroner and Milberg (1995) and Hunt (2016) mentioned how the scientific or positivistic orientation of economics excluded normative contributions or insights into economic phenomena. Malkawi (2014) explained that the Western approach to knowledge perceived such contributions subjectively. This is a philosophical problem of mainstream economics that caused many issues. This paper addresses the issue through appraising IE development as the solution through loK based on IOK.

The physicalist ontology is recognised by its conceptualisation of human nature as material, materialistic, self-interested, greedy yet rational (Brue \& Grant, 2012). Arif $(1985,1987)$ highlighted how Smith's theory of moral sentiments gradually shifted and gained features of such an ontology via stratification $^{7}$ to systematise economic thinking in ways similar to the mathematics and physics of the day (Pribram, 1983; Mahomedy, 2016, 2017). Such a shaped physicalist ontology that perceived only matter and tangible objects as a source of value led to intensified economic thinking with an imperialist and colonialist mindset that spread throughout the world in

\footnotetext{
${ }^{5}$ See the origin of the term in Mahomedy $(2016,2017)$.

${ }^{6}$ It can be traced back to the $13^{\text {th }}$-century Thomistic phase of economic thought (characterized by the philosophical thought and writings of Thomas Aquinas (1225-1274 AC) concerning Catholic Christian ethical and moral teachings), rooted in Christian ethics, morality, and values aimed to end oppressive class relationships of those and earlier times with the help of Christian paternalistic ethic (CPE). The ethic was eventually abused by elites/lords of subsequent centuries feudalistic system that led to what was characterized as the 'first phase of distancing from CPE or also called the maturing phase'. Subsequent mercantilism phase of economic thought (where the CPE in the hands of the church weakened and shifted to mercantilist capitalists.) aggravated it and led to the 'second phase of distancing from CPE or the mature phase' that shaped ontological physicalism in the real sense, empowered the protestants' ethic to defeat the catholic church as the paternal authority and gradually nurtured the positivistic way of thinking (Hunt, 2016; Mahomedy, 2016, 2017). Systematized enlightenment writings reflected the shift from concerns about moral sentiments to positivistic thinking even more and so further fostered ontological physicalism. For more detail see enlightenment economics writings of Adam Smith (1723-1790), David Hume (1711-1776), Robert Malthus (1766-1834), David Ricardo (1772-1823), Jeremy Bentham (1748-1832), his students James Mill (1773-1836), Joh Stuart Mill (1806-1873).

${ }^{7}$ Stratification starts with abstract thinking that usually involves values, norms, ethics, morality and as such help link it with more systematized products of thought that enable appreciation of it and presentation systematically. However, the promise for success is absent. That is apparent in the stratification attempt of economics as a science from moral sentiments. In return, it shows the need for a revision of present economics whose issues root back into the early years of development (Arif, 1985, 1987).
} 
Omercic, Haneef, \& Omar $\mid$ Economic Thought, Foundational Problems of Mainstream Economics and the Alternative of Islamic Economics

the $18^{\text {th }}$ and $19^{\text {th }}$ centuries with destructive and exploitative consequences (Said, 1979; Mirakhor, 2020; Jomo, 2020).

The problem of physicalist ontology became embedded in mainstream economics. Since the Great Depression, it has caused significant unemployment, inflation, unsustainable living, poverty, inequality, etc. (Stiglitz, 2016, 2019). Ten smaller recessions since World War II followed ${ }^{8}$ (Hunt, 2016; Froyen \& Low 2001; Froyen, 2009) due to such an ontology and the rationalist epistemology, axiological futility, and methodological deficiency of mainstream Western economics. Neither mainstream orthodox economics nor heterodox variants addressed this ontological problem of mainstream economics nor resolved the created issues.

Such an ontology that levels everything to matter, contradicts the human constitutions comprising body and soul. For example, the competitive maximisation of material wealth worsened inequality, poverty, unemployment levels, and neglected human religious, spiritual, emotional, and psychological dimensions of meaning (Chapra, 2016). Such are nonmaterial needs ensuring social welfare which historical experience valued for centuries alongside material welfare (Bakar, 2019; Nasr, 2006). Therefore, it is necessary to cater to the material and spiritual needs of humanity. Hence, this paper proposes IE development via loK based on IOK as an alternative ontological foundation.

\subsubsection{Rationalist Epistemology}

Epistemology is the theory of knowledge (Merriam-Webster, 2004). Because of the interrelatedness of ontology and epistemology (Blaug, 1997), the mainstream economic physicalist definition of the nature of beings (ontology) affected the epistemological development of a theory of knowledge in economics followed by futile axiology and deficient methodology. Like the physicalist ontological foundations of mainstream economics, the rationalist epistemology was gradually nurtured since the $16^{\text {th }}$ century but drew its roots from earlier medieval times (Froyen \& Low, 2001, Froyen, 2009; Lin, 2015). The positivistic shift with a physicalist ontology shaped the rationalist epistemology and adopted only senses and reason as sources of knowledge. The recognition of rationalist axioms guided by reason and empiricism based on experience derived from senses led to the rationalist epistemology of mainstream economics (Mahomedy, 2016, 2017). It claims that the theory of knowledge is solely derived from reason

\footnotetext{
${ }^{8}$ To name a few: 1948-1949 for eleven months, 1953-1954 for thirteen months, 1957-1958 and 1960-1961 for nine months, 1969-1971 for more than two years, 1974-1975, 1979-1980, 1981-1982, 1990-1991, etc. (see Hunt, 2016).
} 
Omercic, Haneef, \& Omar $\mid$ Economic Thought, Foundational Problems of Mainstream Economics and the Alternative of Islamic Economics

and senses. Thus, mainstream economics considered everything metaphysical and intangible irrelevant. Such an epistemology conceptualises a problematic homo economicus by limiting the human being to material needs while ignoring other psychological, social, or spiritual needs.

Another issue of such an epistemology led to pure attempts of replication of physics. The two issues caused mainstream economics' theoretical disjointedness from reality. More serious alternatives emerged only in the 1930s with Keynesian economics leading the way yet ultimately failing despite being more social welfare-oriented with later alternatives proving no different (Mahomedy, 2016, 2017). Hence, mainstream economics dominated the economic narrative and practice as a science with shallow ontological and epistemological foundations (Mahomedy, 2016, 2017; Furqani, 2012; Mirakhor, 2020).

Continuing with the same epistemological foundation in contemporary times offers no future for economics or humanity at large and demands a critical review of its development and critique. Otherwise, issues of unemployment, poverty, inflation, instability, inequality, indebtedness, climate change, environmental destruction, desacralisation will persist and worsen. The 2008 Global Recession is the most recent outcome of such foundations guiding economic analysis (Stiglitz, 2016, 2019; Geithner, 2015; Greenspan, 2008). Since then, there has been renewed interest in mainstream economics to improve the adoption of heterodox economic thought (Lee \& Lavoie, 2013). However, it still does not address the foundational problems of mainstream economics like epistemology.

While the rationalist epistemological approach of mainstream economics bases best outcomes on value maximisation, zero-sum games, etc., it exponentially exacerbates the health of global economics with all earlier mentioned issues. It enables participation of the affluent and leaves greater social segments outside the workings of the economic system (Galbraith, 1987, 1998; Stiglitz, 2016, 2019). Hence, analysing the rationalist epistemology at work in contemporary fluctuating markets led economists to use more social, psychological, behavioural, and moral elements to predict market behaviour more accurately (ISRA, 2018; Stiglitz, 2019; Shiller, 2019). Apparent real-life issues caused by such rationalist epistemology justifies this paper's IE development in light of IoK based on IOK to overcome that problem. 
Omercic, Haneef, \& Omar $\mid$ Economic Thought, Foundational Problems of Mainstream Economics and the Alternative of Islamic Economics

\subsubsection{Axiological Futility}

Axiology is defined as the theory that studies the nature, type, and criteria of value, value judgements, especially in ethics (Merriam-Webster, 2004). Human nature leads people to contemplate and wonder, and according to Nasr (2006), the Greek and Roman civilisation are a multidisciplinary outgrowth of philosophising about value, ethics, and morality. Axiology as an element of philosophical foundations in economics undoubtedly played a big role in early economic thought but the positivistic oriented mindset expelled it centuries later (Hunt, 2016; Furqani, 2012). Nienhaus (1989) explained how economic thought before the middle of the $19^{\text {th }}$ century incorporated greater moral, ethical, and value considerations while it became completely neutralised until today. That created the problem of axiological futility.

An orientation towards the mastery of technical tools of quantification became dominant (Haneef, 2014). It shaped the market demand for labour with the greatest ability to maximise firm profits. Axiological futility and its neutrality in economics rendered it irrelevant in studies. However, contemporary complex market structure led to issues of asymmetric information and agent contract theory that demand a greater role of ethics, morality, and values in providing complete information and structuring contracts fairly with the greatest transparency. A futile axiological mainstream economics approach cannot resolve the issue completely without greater behavioural insights and analysis in economics (Shiller, 2015). Thus, the greater role of ethics, morality, and unique aspects of value becomes significant today what inevitably revives the relevance of axiology in economics (Chapra, 2016; Stiglitz, 2019). Therefore, a greater need for axiological reasoning in economics challenges the status-quo of mainstream economics. ${ }^{9}$ Its absence in mainstream economics intensifies financialisation and perpetuates other issues (Chapra, 2017; Mirakhor, 2020). While the futility of axiological role (ethics, morality, values) in mainstream economics created moral and ethical disorientation in societies, empirical evidence revealed the greater need for morality and ethics in socio-economic and other relations (Stiglitz, 2019; Mirakhor, 2020). Hence, the need for the development of an alternative to mainstream economics like IE with strong axiological foundations that this paper proposes in light of loK based on IOK.

\footnotetext{
${ }^{9}$ See also Medearis (2009), Dunn (2012), Lee and Lavoie (2013), Gordon and Adams (1989), Black (1986) for greater detail.
} 
Omercic, Haneef, \& Omar $\mid$ Economic Thought, Foundational Problems of Mainstream Economics and the Alternative of Islamic Economics

\subsubsection{Methodological Deficiency}

Methodology is defined as a body of methods, rules, procedures, and postulates used in a discipline to analyse, explain, attain certain objective/s (Merriam-Webster, 2004). Mainstream economics developed a substantial methodological body of knowledge over the centuries of the development of economics. Discourse about methodology in economics continues today and differences of opinion exist in what a complete methodology involves (Machlup, 1978). With the philosophical foundations of mainstream economics discussed earlier, perceptions of the human as purely materialistic, self-interested, utility and wealth maximiser yet rational being led to the development of the methodology of economics aiming to attain it. Thus, the methodology of mainstream economics relates to processes of thinking that shaped views of external reality in an incomplete and particularistic manner (Malkawi, 2014; Mahomedy, 2016, 2017). Machlup (1978) explained that historically, metaphysical, spiritual, and moral/ethical (axiological) aspects as parts of the 'Map of Territory' of philosophy were relevant in ontology, epistemology, and methodology. ${ }^{10}$ Different interpretations of each of the elements over the centuries of development of economic thought created confusion in thinking due to foundational problems. Today, the methodology of mainstream economics rejects elements like spirituality, morality, and ethics.

Such a deficient unidimensional methodology perpetuated issues of rising inequalities, multiple crises, environmental disasters, and wars (Malkawi, 2014). The mechanical methodology exercised with a focus on numerical, mathematical, statistical and econometric techniques exacerbates the above issues because the obsession with getting appropriate estimated samples, determining the range and defined benchmark values has distracted attention to issues of rising poverty, unemployment, public and government debt levels and unsustainable lifestyles, etc. (Keen, 2011; Piketty, 2014). Such a partial methodological analysis of problems of reality produced technical economists in contemporary times, who rarely preach their ideas to the world. While sophisticated mathematical and other technical modelling increase the economics abstractness from reality, there are frequent economic instabilities, crises, asymmetric information and risks (default, exchange, market risk, etc.) (Ariff, 2020; Mirakhor, 2020; Jomo, 2020).

\footnotetext{
${ }^{10}$ Machlup (1978) mentioned Kant, Windelband, Royce, Croce, Max Weber, Montague, Bridgeman, Whitehead, Moris Cohen, Reichenbach, Felix Kaufmann, Schutz, Carnap, Morgenau, Popper, Feigl, Braithwaite, Ernest Nagel, and Hempel as examples of more dynamic thought in economics. The methodology involved ontology and epistemology or ontology involved epistemology and methodology or epistemology involved ontology and methodology or otherwise. Even metaphysics existed for some and was relevant (Machlup, 1978).
} 
Omercic, Haneef, \& Omar $\mid$ Economic Thought, Foundational Problems of Mainstream Economics and the Alternative of Islamic Economics

Furthering such methodological practices renders economic analysis, output, products susceptible to fallacies of the scientific paradigm that are probability-based or pure numerical signs of growth (Putnam \& Walsh, 2012). For example, measurements of gross domestic product (GDP), nominal or real, as an indicator of economic growth is numerical and do not reflect the genuine economic, social, political, religious-spiritualpsychological wellbeing of society. It is unidimensional and an example of aggregate measurements that may reduce indicators of acute economic depressions but does little to ensure genuine social multidimensional wellbeing (Stiglitz, 2019; Piketty, 2014). Such measurements are part of the financialisaton and aerobics of accounting practices that benefit the affluent who aggregately control markets and maintain others subservient to them (Stiglitz, 2016, 2019; Lin, 2015). Hence, it became a fact today that mainstream economics suffers from severe methodological deficiency besides earlier discussed problems of philosophical foundations. That relevantises this paper in proposing IE development in light of IoK based on IOK to resolve such problems.

\section{Methodology}

Prior to presenting the results and analysis through exploring the Muslim responses to earlier gaps as reviewed foundational problems of mainstream economics, we explain the methodology adopted in this paper. The paper adopts a qualitative approach in the form of a literature survey, discourse and critical content analysis. According to Denzin and Lincoln (2008), qualitative research is a positioned undertaking that finds the observer on a planet composed of interpretable script made of books, articles, manuscripts, interviews, etc. that make the world perceptible to everyone, change thoughts and the world. Qualitative methods permit and empower the researcher to instigate an erudite, refined but classy, stylish, holistic, and exhaustive comprehension of the objectives of a study via stepwise arduous data collection and analysis. According to Ritchie and Lewis (2003), the result of the entire process generates reliable and validated synthesis of inputs as solutions within an elaborated context that is not generalisable like any study.

This paper also adopted a non-customary methodological pluralism throughout. It combined the method of concretisation (from general to particular and vice versa), comparative method, historical method, and methods of logic (induction, deduction, analysis, synthesis, analogy, logical abstraction, and generalisation) in the content analysis and library research 
Omercic, Haneef, \& Omar $\mid$ Economic Thought, Foundational Problems of Mainstream Economics and the Alternative of Islamic Economics

throughout this paper. Hadzic (2005) perceived this as an unorthodox and unique methodological pluralism because of the unique nature of $\mathrm{IE}$ and development in this paper. The unique methodology of IOK and IE with sources of knowledge in Islam stands for tawhid (belief in one God and unity of knowledge), Qur'an as Revelation, Sunnah as Prophetic PBUH heritage, figh and usul al-figh, or others and compels us to integrate the respective methodologies to understand each aspect in this paper. Hence those are relevant and complementary methodologies for appraisal of IE and its methodology through an loK based on IOK in this paper but also for the way forward in IE development via loK. Since this paper is a contribution to the methodology of IE, then such methodological pluralism becomes incumbent and commendable. This paper aspires to instigate research in IE through loK based on sound foundations and serve the humanity. It is for those reasons that the methodology adopted in this paper is foundational for this and future studies.

\section{Results and Analysis}

\subsection{Muslim Responses}

The physicalist ontology, rationalist epistemology, axiological futility and methodological deficiency problems of mainstream economics' philosophical foundations faced varying responses. Since intensifying colonialism from the $16^{\text {th }}$ century, Muslims gradually intensified the resistance to the West. In such an effort, IE emerged in contemporary times as an alternative to mainstream economics and most importantly the above foundational problems. Although humanity lives better than centuries ago because of contributions of mainstream economics, the need for reforms of philosophical foundations and contents of the discipline is urgent. A brief review of Muslim responses to mentioned foundational problems of mainstream economics represent our results or findings and promotes a novel approach of developing the alternative IE in light of IOK to filter and integrate mainstream economics with comprehensive ontological, epistemological, axiological, and methodological foundations (Mirakhor, 2020). 
Omercic, Haneef, \& Omar $\mid$ Economic Thought, Foundational Problems of Mainstream Economics and the Alternative of Islamic Economics

\subsection{Iṣlạ (Reform) and Tajdìd(Renewal) Movements}

Throughout centuries, ișlah (reform) and tajdìd (renewal) movements have revived the thought and improved lifestyles in Muslim societies ${ }^{11}$ (De Bellaigue, 2017). The aim was to reinstate genuine Islamic teachings. The debates about the use and role of reason and transmitted tradition/revelation ( $a^{\prime} q l$ and naql/wahy) were always of significant concern to the Muslim intelligentsia. ${ }^{12}$ Essentially, the debates were methodological and linked to philosophical foundations, namely ontology, epistemology, and axiology. The scholars worried about the overuse of reason, rejection of reason, infringement of revelation, and limitations of interpretation of revelation (Malkawi, 2014; Hallaq, 2005, 2009).

Reform and renewal movements always touched upon and addressed philosophical foundations and worldview problems that mainstream economics suffers from. However, the discourse lacked focus on methodology and methods to develop alternatives to mainstream economics like IE. The discourse was customarily dynamic and of a multidisciplinary, holistic, or pluralist methodological nature, and became popular in contemporary times (Haneef \& Furqani, 2015 in El-Karanshawi et al., 2015; Walbridge, 2011)..$^{13}$ Unlike the nature (ontology) of homo economicus of mainstream economics, Islam always perceived it as homo Islamicus, which incorporates material and non-material (metaphysical) dimensions, altruism, and social welfare orientations, etc.. Muslim responses incorporated comprehensive and holistic foundations, namely an ontology that went beyond physicalism to the metaphysical realms; an epistemology that sourced knowledge from reason, senses, revelation (metaphysics) that involves axiology (ethics, morality, and values) inevitably; and a methodology with a broad scope to address human needs as objectives/maqasid. It was always an integrative nexus of foundations that sought to attain the ultimate truth - haqq.

In contemporary times, Islamisation of Knowledge $(\mathrm{IOK})^{14}$ is an intellectual movement with ontological, epistemological, axiological, and methodological

\footnotetext{
${ }^{11}$ Reformers came at the verge of every hundred years according to the saying of the Prophet Muhammad, peace and blessings upon him (PBUH): "Allah at the head of every century will raise for this Ummah someone who will revive Her Religion for Her." (Abu Dawud, 2000, no. 4291). The Hadith prophesized reformers' inevitable coming and the occurrence of religious crises after the death of the Prophet Muhammad PBUH.

${ }^{12}$ It was partially nurtured by the declaration of the halt of ijtihād (Muslim legal reasoning) around $10^{\text {th }}$ century AD. The condition and circumstances of the Muslim intelligentsia since the $10^{\text {th }}$ century onwards but even earlier is far more complex but the debate on reason and tradition/ revelation is sufficient to frame this paper as primarily methodological (Malkawi, 2014; Walbridge, 2011).

${ }^{13}$ See also Putnam and Walsh (2012); Aydin (2013); Nienhaus (1989); Mahyudi (2016) etc..

${ }^{14}$ The reform and renewal movement of IOK is traceable to times of Prophet Muhammad, PBUH until today but was shaped as IOK in the middle of $20^{\text {th }}$ century (Al-Faruqi, 1982; Nasr, 2006).
} 
Omercic, Haneef, \& Omar $\mid$ Economic Thought, Foundational Problems of Mainstream Economics and the Alternative of Islamic Economics

foundations. It is a methodological process rooted in ontological, epistemological, and axiological foundations aiming to refine legacy/classical and modern bodies of knowledge in relation to sources of knowledge in Islam that are equally universal and particular (Al-Attas, 1978; Safi, 1993; Haneef, 1997). The counterpart in economics is IE what renders IOK a relevant methodological approach to develop IE (Haneef, 2014). However, considering the experience of IOK development (Sardar \& Henzell-Thomas, 2017; Haneef, 2014), Integration of Knowledge (IoK) is today a more natural and neutral approach for IE development that this paper appraises based on IOK because of common and sound philosophical foundations. An loK approach to IE development based on IOK enables fusion of extant contributions to IOK and IE into outputs that foster genuine IE development along being the solution to problems of mainstream economics (Furqani, 2012). However, this requires more thorough study in future.

\subsection{Is lah and Tajdi d Through Islamisation of Knowledge (IoK) and Islamic Economics (IE) - Why IOK, and What Does IOK Mean to IE?}

Since inception, IOK aimed to filter, change, refine, and integrate Islamic and Western bodies of knowledge. IE attempted this task in the discipline of economics. The two were almost parallel developments in the $20^{\text {th }}$ century. While resemblance and influence between the two exist, the IOK methodological approach was not explicitly applied for IE development. It is important to say that IE was perceived as the greater success of IOK. Both created high enthusiasm and revealed unleashed potential to humankind (Haneef, 2014; Sardar, 1989; Sardar \& Henzell-Thomas, 2017). The common and comprehensive foundations make both a creative approach in developing IE to overcome problems of mainstream economics discussed in earlier sections. It is with these foundations that Muslims always responded to the West and mainstream economics as with IOK and IE, respectively. The methodology is common for both but particular for IE as a discipline. That is evident from extant methodological writings in IE such as Furqani and Haneef (2012). Thus, IOK is a sound basis upon which to develop a genuine IE and its methodology. The sound philosophical foundations transcend the foundational problems of mainstream economics beyond the physicalism in ontology to metaphysics, beyond reason and experience in epistemology to revelation/metaphysical channels of knowledge, emphasizes axiological moral/ethical role in dealing with economic and other phenomena as well as adopts a pluralist methodological approach. These are clear findings that autonomously represent a potential to transform humanity problems into sustainable solutions. 
Omercic, Haneef, \& Omar $\mid$ Economic Thought, Foundational Problems of Mainstream Economics and the Alternative of Islamic Economics

Meanwhile, we appraise in this paper the Integration of Knowledge (IoK) as a term that is more neutral, inclusive, and universally appealing than Islamisation of Knowledge (IOK). ${ }^{15}$ However, any integration must be based on something and in this paper loK is based on IOK. Hence, IOK for IE development based on IOK to overcome earlier identified problems of mainstream economics. It is then clear that IOK, IOK, and IE refer to the same sources of knowledge including those of the West (Furqani, 2012). Definitions of IOK and IE reflect it directly and facilitate understanding the IoK based approach to IE development in this paper as an alternative to overcome problems with mainstream economics. Al-Attas (1978) defined IOK with reference to knowledge as:

"with reference to God as being its origin, is the arrival (husul) in the soul of the meaning (ma'ana) of a thing or an object of knowledge; and with reference to the soul as being its interpreter, knowledge is the arrival (wusul) of the soul at the meaning of a thing or an object of knowledge." (p. 161)

Hence, it is the process of gradually discovering the meaning of the object of knowledge with our rational and spiritual faculties, the mind and the heart as the seat of human intellect where integration or a link of knowledge and human faculties becomes apparent. These reflect an ontology beyond physicalist realms and an epistemology with physical and metaphysical sources or channels of knowledge. The role of akhlaq/ethical (axiological) and pluralist methodological approach is also integral and welcoming within the broad philosophy of integration based on Islamisation (Al-Attas, 2014). In a later section, Al-Attas (1978) explains IOK:

"after the isolation process referred to, the knowledge free of the elements and key concepts isolated are then infused with the Islamic elements and key concepts which, in view of their fundamental nature as defining the fitrah, in fact, imbue the knowledge with the quality of its natural function and purpose and thus makes it true knowledge." (p. 162-163)

Thus, unnecessary elements are removed from knowledge and imbued with necessary elements and concepts derived from sources of knowledge in Islam (Haneef, 1997). That then reflects the pure nature of knowledge and enables it to have its function and purpose to attain the truth and reality, haqq and haqiqah (Furqani, 2012). The sources of knowledge are of course an epistemological aspect that equally refers to ontology. Both pay attention to the centrality and interplay of revelation and reason guided by a revelation-based ethics (axiology) in line with reason. The methodology recognizes plurality of methodological approaches in such a nexus of

\footnotetext{
${ }^{15}$ It was the International Institute of Islamic Thought (IIIT's) that promoted the shift from Islamization to Integration in the $21^{\text {st }}$ century what justifies the use of loK in this paper (Sardar \& Henzell-Thomas, 2017). IIIT is a non-profit intellectual organization that promotes IOK but emphasizes integration as a key focus in the $21^{\text {st }}$ century.
} 
Omercic, Haneef, \& Omar $\mid$ Economic Thought, Foundational Problems of Mainstream Economics and the Alternative of Islamic Economics

ontology, epistemology and axiology. Similarly, IOK is for Isma'il Raji AlFaruqi's (1982) to 'recast knowledge as Islam relates to it':

"to redefine, and reorder the data, to rethink the reasoning and relating of the data, to reevaluate the conclusions, to re-project the goals, and to do so in such a way as to make the disciplines improve the vision and serve the cause of Islam (peace)." (p.44-50)

IOK has a universal and particular appeal to humanity and Muslims to attain peace through disciplinary perfection and attainment of what Al-Attas defined as truth and reality. With the shift to loK today, we particularise the idea to integrate Islamic and modern bodies of knowledge through critical multidisciplinary interaction to overcome problems and issues like those of mainstream economics. It reflects and revives the Islamic tradition of differences of opinion (Walbridge, 2011) and pluralist methodology that the Prophet (PBUH) addressed as mercy for mankind. Like IOK, IE practice is traceable in the history of Islamic civilisation, yet modern IE is a construct of the $20^{\text {th }}$ century (Irfan, 2015). Haneef (1997) defined IE as:

"an approach to interpreting and solving man's economic problems based on the values, norms, laws, and institutions found in, and derived from, the sources of knowledge in Islam." (p. 50)

The definition of IE, and that of IOK, reveals that knowledge of each is derived from the same sources and both have the same objectives. While revelation is central for $\mathrm{IE}$, reason is given no less attention than in mainstream economics. What differentiates the former from the latter is the source of guidance from the revelation that is and must be universally appealing to humanity, yet in principle particularly important for Muslims. Thus, our earlier analysis of the findings of robust philosophical foundations of IOK as a Muslim reform and renewal response to the West apply to IE as a response to mainstream economics. Hence, IE development through loK based on IOK as the alternative and solution to foundational problems and issues of mainstream economics.

We proposed in this paper the IE development with such universal appeal and sound philosophical foundations in light of loK based on IOK as an alternative and solution to problems of mainstream economics. IE does not reject mainstream economics outrightly in that process but selectively integrates excellent practices (Chapra, 2016; Furqani, 2012). IE development via loK carries the methodological proposition to humanity's economic and other issues and problems subject to improvement yet linked with sound foundations unlike mainstream economics (Malkawi, 2014). The relevance of IoK for IE is apparent, and such a nexus or framework of loK for IE development would suit this papers objective to overcome foundational problems of mainstream economics but even further development of IE. 
Omercic, Haneef, \& Omar $\mid$ Economic Thought, Foundational Problems of Mainstream Economics and the Alternative of Islamic Economics

Although Mahomedy (2016, 2017) and others such as Furqani (2012) attempted to appraise IE earlier, they proposed no particular and practical systematic direction for IE development via a nexus with IoK based on IOK, as undertaken in this paper. Hence, mainstream economics continued to dominate the Muslim world. Its problems persisted for centuries until today and very notable chronic issues are extravagant debt financing and spending amidst extreme inequalities and instabilities, rising unemployment, inflation and debt, environmental devastation and climate change, dehumanisation, and desacralisation of everything (Stiglitz, 2016; 2019).

Because of all the above, this paper perceives the current state of mainstream economics with its problems and approach to knowledge as a reason for today's confusion and crisis in economic thinking. It represents the problem of this paper as a theoretical account that we addressed thoroughly and systematically through reviewing the IOK and IE Muslim responses with robust philosophical foundations. However, much needs to be addressed in practice to dispel and prevent deepening of such mainstream foundational problems and further issues affecting humanity.

The heterodox economics including the thought of post-modernists/social constructivists proposed some remedies (Kuhn, 1970, 2012; Lee \& Lavoie, 2013). However, they adopted the problematic philosophical foundations of mainstream economics. That perpetuated the problems and issues for many decades. Hence, there is an apparent need for an alternative approach to economics with sound, comprehensive and holistic ontological, epistemological, axiological, and methodological foundations to overcome the problems of mainstream economics mentioned above. IE development in light of loK is the alternative we appraised based on IOK. The robustness of this integrative or IoK approach to IE development requires future intellectual and practical insights and efforts respectively. As such, it is with these theoretical constructions that awareness of upcoming generations is raised to carry out the amanah (responsibility, burden) with genuine determination.

\subsection{The Significance of IE development via IoK based on IOK as the Alternative}

The significance of this paper's IE appraisal in light of loK based on IOK is its multidisciplinary methodological principles-based approach of integrating legacy/classical and modern bodies of knowledge to overcome problems of mainstream economics. Integrating the bodies of knowledge focuses on economics yet includes contributions from other disciplines. This approach is 
Omercic, Haneef, \& Omar $\mid$ Economic Thought, Foundational Problems of Mainstream Economics and the Alternative of Islamic Economics

perhaps the first of its type that directly adopts the methodological approach of IOK for IE development. It demonstrates how to overcome problems with mainstream economics on ontological, epistemological, axiological, and methodological bases without neglecting the contributions of mainstream economics.

The contribution of this paper's proposition significantly expands the frontiers of multidisciplinary research in economics. We can characterise it as an Ibn Khaldunian approach that fosters more multidimensional approaches to solving human economics and other problems (Chapra, 2016; Khan, 2013, 2013a; Alatas, 2014). Besides the above, the appraisal of development of IE in light of IoK based on IOK in this paper directs future research based on sound ontological, epistemological, axiological, and methodological foundations that universally appeal to humanity and particularly to Muslims.

Another significance of the appraised in this paper is reviving the relevance of Islamic and other legacy studies to the development of economics, particularly IE. It links its role in the development of economics in the past and today. Our approach clarifies the universal dimensions of IOK and IE as contemporary developments beneficial to humanity. It likewise clarifies no harm in benefiting from Western bodies of knowledge like mainstream economics that scholars like Haneef (1995, 2014), Ramadan (2009, 2009a), Malkawi (2014) strived to promote. That holds true despite the foundational problems of mainstream economics.

The appraised development of IE in this paper contributes to re-linking the Islamic Banking and Finance (IBF) industry and ensuring it is based on sound IE foundations. It directs IBF development in relation to and within the IOK based IE development. Hence, stakeholders who shall benefit most from this undertaking are academicians and researchers through the additional stock of knowledge and a new methodological approach and development of methodological principles to validate theories and integrate knowledge. Students may learn how important studies of ontology, epistemology, axiology and methodology are as philosophical foundations that shape the worldview of individuals. It highlights the importance of methodology and methods as tools of inquiry in relation to foundations that guide the reasoning/ijtihad within the overall worldview that helps determine if something is sound or not. Hence, the paper is educational material for everyone. Even policymakers may learn how our appraised approach facilitates future economic policymaking to benefit humanity. Lastly, the current paper is a novel contemporary blueprint for IE development subject to improvement. 
Omercic, Haneef, \& Omar $\mid$ Economic Thought, Foundational Problems of Mainstream Economics and the Alternative of Islamic Economics

\section{Conclusion And Recommendation}

\subsection{Conclusion}

In this paper, we identified foundational problems of mainstream economics and appraised IE as the alternative and solution. We appraised IE development in light of loK based on IOK because of the need for integration to have a basis but also as a result of challenges of development faced by IOK and IE over the decades. We have seen that a persistent mainstream economic's physicalist ontology limits the understanding of reality despite much non-physicalist experience throughout history. Likewise, a rationalist epistemology indicated the limitation set upon human potential to harmonise the physical with metaphysical sources of knowledge and foremost limits the human understanding of reality (haqiqah) and truth (haqq). Axiological futility apparently deprived humans from valuing reality accordingly and treating it with utmost ethics and morality. All of the above explains the problem of methodological deficiency. Limitations and deprivation with the earlier problems restricted proper methodological reasoning over reality of life and economic phenomena particularly. Collectively, such philosophical foundations of mainstream economics were the source of uncounted economic and issues of other sort. Humanity at large bears the consequences of the issues even today. However, we noted that the sound foundations of IOK and IE expand the ontology and epistemology with metaphysical realms of reality and channels of knowledge guided by ethics (axiology). These enable the human perception of reality of life and economic phenomena holistically along with the pluralist methodological engagement while actualizing the defined objectives/maqasid. Muslims always responded with such comprehensive foundations to the West and mainstream economics particularly. Indicatively, these findings expand the horizon of humans and identify the errors of historical perception in economic thought. It is for these reasons that IE development in light of IoK based on IOK is central. Humanity necessitates a universal interpretation of reality and economics per se because the nature of life and reality of globalization demands it. Multidisciplinarity is attainable via integration within disciplines like IE and such benefits particular and all disciplines simultaneously because all are interconnected. 
Omercic, Haneef, \& Omar $\mid$ Economic Thought, Foundational Problems of Mainstream Economics and the Alternative of Islamic Economics

\subsection{Recommendations}

Today, the practice of mainstream economics led many to question the purpose, structure and orientation of the discipline. Firstly, our recommendations for everyone are to ponder about how history is replete with facts of much metaphysical experience along the physical or material experience. Likewise, we recommend adding revelation and religious/spiritual traditions and ethics as central sources of knowledge along reason and sensual experience. Reference to writings of philosophy would make it obvious to be part of any discipline's foundations and origin. With that in mind, we recommend the integration of all the above in methodological processes of reasoning in economics or other disciplines. It is necessary to deeply contemplate about the implications that the failure to adopt given recommendations would cause.

Our recommendation to practitioners, inclusive of academia and industry, is to always perceive the necessity of thought about the philosophical foundations (ontology, epistemology, axiology and methodology) in order to understand and explain phenomena holistically. Greater adoption and development of trainings, seminars, workshops in industry and academia on what those foundations imply would represent a great platform where experts of texts and contexts may exchange their views. Hence, practitioners may correct their perception about reality and accordingly revise many undergoing projects in relation to more universal philosophical foundations and avoid limitation and potential consequential issues of a narrow perception. We recommend the practitioners to use and integrate the renewed perception of reality with social needs, starting from the necessities (daruriyyat), the commendable (hajiyyat) and the luxuries (tahsiniyyat) as the practical objectives of Shari'ah.

Our recommendation for regulators is to integrate with the efforts of practitioners the implementation of various projects on ground. A particular recommendation for regulators is to oversee, evaluate and effectively ensure communication among and within different institutions, parties, shareholders and stakeholders, givers and receivers of services. This would ensure that the impact of projects and a renewed perception of reality on sound foundations is maximised while any repercussions eliminated.

This paper is a blueprint that intends to shape the way we think about economics and life generally. Hence, it is subject to improvement. Future research may explore the way different institutions perceive appraised foundations in this paper and avenues of realigning institutional and theoretical efforts towards a common integrated (IOK) based socio-economic development. Future researchers may do field work of IE development via 
Omercic, Haneef, \& Omar $\mid$ Economic Thought, Foundational Problems of Mainstream Economics and the Alternative of Islamic Economics

loK where engagement with a number of practitioners, industry and academia, brings integrative output such as projects, seminars, workshops and how those benefit society. That would help crystallise our appraised approach to IE development through IoK and help resolve the embedded foundational problems and recurrent issues caused by the approach of mainstream economics. 
Omercic, Haneef, \& Omar $\mid$ Economic Thought, Foundational Problems of Mainstream Economics and the Alternative of Islamic Economics

\section{References}

Alatas, S. F. (2014). Applying Ibn Khaldūn: The recovery of a lost tradition in sociology. New York: Routledge.

Al-Attas, M. N. (1978). Is/ām and secularism. Kuala Lumpur: Muslim Youth Movement of Malaysia.

Al-Attas, S. M. N. (2014). Prolegomena to the metaphysics of Islam. Kuala Lumpur: Penerbit UTM Press.

Al-Faruqi, I. R. (1982). Islamization of knowledge: The problem, principles and the workplan. Herndon: International Institute of Islamic Thought (IIIT).

Ali, A., \& Thompson, H. (1999). The Schumpeterian gap and Muslim economic thought. Journal of Interdisciplinary Economics, 10(1), 3149.

Ali, M. (2016). Islamization of modern science and its philosophy: A contemporary civilization discourse. Kuala Lumpur: IIUM Press.

Arif, M. (1985). Toward a definition of Islamic economics: Some scientific considerations. Journal of King Abdulaziz University: Islamic Economics, 2(2).

Arif, M. (1987). The Islamization of knowledge and some methodological issues in paradigm building: The general case of social science with a special focus on economics. American Journal of Islamic Social Sciences (AJISS), 4(1), 51.

Ariff, M. (2020). Economic and financial crises: Can Islamic economics and finance make a difference?. Institute Kefahamatan Islam Malaysia (IKIM). IKIM National Colloquium Series on Islamic Understanding. Kuala Lumpur: IKIM.

Aydin, N. (2013). Redefining Islamic economics as a new economic paradigm. Islamic Economic Studies, 130(607), 1-34.

Bakar, O. (2019). Classification of knowledge in Islam: A Study in Islamic Schools of Epistemology. Kuala Lumpur: Islamic Book Trust.

Black, R. C. (Ed.). (1986). Ideas in economics. New Jersey: Springer.

Blaug, M. (1997). The methodology of economics: How economists explain. Cambridge: Cambridge University Press.

Boşca, L. C. (2015). Criticism of conventional economy and of the homo economicus paradigm in the philosophy of Islamic economy. CogitoMultidisciplinary research Journal, (1), 77-89.

Brue, S., and Grant, R. (2012). The evolution of economic thought. Ohio: Cengage Learning. 
Omercic, Haneef, \& Omar $\mid$ Economic Thought, Foundational Problems of Mainstream Economics and the Alternative of Islamic Economics

Canterbery, E. R. (1987). The making of economics. Belmont: Wadsworth.

Chapra, M. U. (2016). The future of economics: An Islamic perspective. Leicester: Islamic Foundation.

Chapra, M. U. (2017). The looming international financial crisis: Can the introduction of risk sharing in the financial system as required by Islamic finance play a positive role in reducing its severity? Islamic Economic Studies, 25(2).

Dawud, S. A. (2000). Sunan Abu Dawud (see Hadith no. 4291). London: Dar al-Fikr.

De Bellaigue, C. (2017). The Islamic enlightenment: The struggle between faith and reason, 1798 to modern times. London: Liveright Publishing.

Denzin, N. K., \& Lincoln, Y. S. (2008). Collecting and interpreting qualitative materials (Vol. 3). California: Thousand Oaks: SAGE Publications.

Dunn, S. P. (2012). The economics of John Kenneth Galbraith. Cambridge: Cambridge Books.

El-Karanshawy, H. A., Omar, A., Khan, T., Ali, S. S., Izhar, H., Tariq, W., \& Al Quradaghi, B. (2015). Islamic economics: Theory, policy and social justice. Doha: Qatar Foundation.

Froyen R. T. (2009). Macroeconomics: Theories and policies. New York: Prentice Hall.

Froyen, R. T., \& Low, L. (2001). Macroeconomics: An Asian perspective. New York: Prentice Hall.

Furqani, H. (2012). The Foundations of Islamic Economics: A Philosophical Exploration of the Discipline. (Doctoral Thesis). International Islamic University Malaysia (IIUM).

Furqani, H., \& Haneef, M. A. (2012). Theory appraisal in Islamic economic methodology: Purposes and criteria. Humanomics, 28(4), $270-284$.

Galbraith, J. K. (1987). A history of economics. London: Hamish Hamilton.

Galbraith, J. K. (1998). The affluent society. Houghton Mifflin Harcourt.

Geithner, T. F. (2015). Stress test: Reflections on financial crises. New York: Broadway Books.

Gordon, W., \& Adams, J. (1989). Economics as social science: An evolutionary approach. Riverdale: Riverdale Company.

Greenspan, A. (2008). The age of turbulence: Adventures in a new world. New York: Penguin. 
Omercic, Haneef, \& Omar $\mid$ Economic Thought, Foundational Problems of Mainstream Economics and the Alternative of Islamic Economics

Hadzic, F. (2005). Islamsko bankarstvo i ekonomski razvoj. (Islamic banking and economic development). Sarajevo: Ekonomski Fakultet, Univerzitet u Sarajevu (Faculty of Economics, University of Sarajevo).

Hallaq, W. B. (2005). The origins and evolution of Islamic law (Vol. 1). Cambridge: Cambridge University Press.

Hallaq, W. B. (2009). An introduction to Islamic law. Cambridge: Cambridge University Press.

Haneef, M. A. (1995). Contemporary Islamic economic thought: A selected comparative analysis. London: Alhoda.

Haneef, M. A. (2014). A critical survey of Islamization of knowledge. Kuala Lumpur: IIUM Press.

Haneef, M. A. \& Furqani, H. (2015). Methodology of Islamic economics: Typology of current practices, evaluation and way forward, in ElKaranshawy, H. A., Omar, A., Khan, T., Ali, S. S., Izhar, H., Tariq, W., ... \& Al Quradaghi, B. (2015). Islamic economics: Theory, policy and social justice. Doha: Qatar Foundation.

Haneef, M. A. M. (1997). Islam, the Islamic worldview and Islamic economics. IIUM Journal of Economics and Management, 5(1), 39-66.

Heilbroner, R. L., \& Milberg, W. S. (1995). The crisis of vision in modern economic thought. Cambridge: Cambridge University Press.

Hunt, E. K. (2016). Property and Prophets: The evolution of economic institutions and ideologies: The evolution of economic institutions and ideologies. New York: Routledge.

Irfan, H. (2015). Heaven's bankers: Inside the hidden world of Islamic finance. New York: Abrams.

Islahi, A. A. (2005). Contribution of Muslim scholars to economic thought and analysis. Jedday: Scientific Publisher Center, King Abdul Aziz University.

Islahi, A. A. (2014). History of Islamic economic thought: Contributions of Muslim scholars to economic thought and analysis. Northampton: Edward Elgar Publishing.

ISRA (2018). Islamic financial system: Principles and operations. Kuala Lumpur: ISRA.

Jomo, K. S. (2020). Capitalism and 'Islamic economics'. Institute Kefahamatan Islam Malaysia (IKIM). IKIM National Colloquium Series on Islamic Understanding. Kuala Lumpur: IKIM.

Keen, S. (2011). Debunking economics: the naked emperor dethroned? London: Zed Books Ltd. 
Omercic, Haneef, \& Omar $\mid$ Economic Thought, Foundational Problems of Mainstream Economics and the Alternative of Islamic Economics

Khan, M. A. (2013). What is wrong with Islamic economics? Analyzing the present state and future agenda. London: Edward Elgar Publishing.

Khan, M. F. (2013a). Theorizing Islamic economics: Search for a framework for Islamic economic analysis. Journal of King Abdul Aziz (JKAU): Islamic Economics (IE), Vol. 26, No. 1.

Koehler, B. (2014). Early Islam and the birth of capitalism. London: Lexington Books.

Kuhn, T. S. (1970). The structure of scientific revolutions. Chicago: University of Chicago Press.

Kuhn, T. S. (2012). The structure of scientific revolutions. Chicago: University of Chicago Press.

Lee, F. S., \& Lavoie, M. (Eds.). (2013). In defense of post-Keynesian and heterodox economics: Responses to their critics. New York: Routledge.

Lin, S. Y. (2015). The global economy in turbulent times. Singapore: John Wiley \& Sons.

Machlup, F. (1978). Methodology of economics and other social sciences. New York: Elsevier Monographs.

Mahomedy, A. C. (2016). The disintegrating force of rationalism on economics: What it means for Islamic economics (No. 611). Economic Research Southern Africa (ERSA). Durban: National Treasury of South Africa.

Mahomedy, A. C. (2017). Why the rationalist foundations of modern science are unsuitable for Islamic economics (Doctoral thesis). University of KwaZulu-Natal.

Mahyudi, M. (2016). Rethinking the concept of economic man and its relevance to the future of Islamic economics. Intellectual Discourse, 24(1).

Malkawi, F. H. (2014). Epistemological integration: Essentials of an Islamic methodology. Herndon: International Institute of Islamic Thought (IIIT).

Merriam-Webster (2004).Merriam-Webster's collegiate dictionary. Massachusets: Merriam-Webster.

Mirakhor, A. (2020). Comments on the theme: "Failure of extreme capitalism - Is Islamic economics the answer?". Institute Kefahamatan Islam Malaysia (IKIM). IKIM National Colloquium Series on Islamic Understanding. Kuala Lumpur: IKIM.

Nasr, S. H. (2006). Islamic philosophy from its origin to the present: Philosophy in the land of Prophecy. New York: State University of New York Press. 
Omercic, Haneef, \& Omar $\mid$ Economic Thought, Foundational Problems of Mainstream Economics and the Alternative of Islamic Economics

Nienhaus, V. (1989). Epistemology, methodology and economic policy: Some thoughts on mainstream, Austrian and Islamic economics. Humanomics, 5(1), 91-112.

Piketty, T. (2014). Capital in the 21st century. Massachusetts: Belknap Press of Harvard University Press.

Pribram, K. (1983). A history of economic reasoning (p. 209). Baltimore: Johns Hopkins University Press.

Putnam, H. \& Walsh. V. (Eds.) (2012). The end of value-free economics. New York: Routledge.

Ramadan, T. (2009). Radical reform: Islamic ethics and liberation. Oxford: Oxford University Press.

Ramadan, T. (2009a). Islam, the West and the challenges of modernity. Leicester: The Islamic Foundation.

Ritchie, J., \& Lewis, J. (2003). Qualitative research practice: A guide for social science students Researchers. London: SAGE Publications.

Safi, L. (1993). The quest for Islamic methodology: The Islamization of knowledge project in its second decade. American Journal of Islamic Social Sciences (AJISS), 10(1), 23.

Said, E. W. (1979). Orientalism. New York: Vintage.

Saliba, G. (2007). Islamic science and the making of the European renaissance. Massachusetts: MIT Press.

Sardar, Z. (1989). Islamization of Knowledge: A state of the art report. An early crescent: The future of knowledge and the environment in Islam, 27-56.

Sardar, Z. \& Henzell-Thomas J. (2017). 'Rethinking reform in higher education: From Islamization to integration of knowledge'. Herndon: International Institute of Islamic Thought (IIIT).

Shiller, R. J. (2015). Irrational exuberance: Revised and expanded third edition. Princeton: Princeton University Press.

Shiller, R. J. (2019). Narrative economics: How stories go viral and drive major economic events. Princeton: Princeton University Press.

Stiglitz, J. E. (2016). The euro: How a common currency threatens the future of Europe. New York: WW Norton \& Company.

Stigltiz, J. E. (2019). People, power, and profits: Progressive capitalism for an age of discontent. New York: WW Norton \& Co.

Walbridge, J. (2011). God and logic in Islam: The caliphate of reason. Cambridge: Cambridge University Press. 
Omercic, Haneef, \& Omar $\mid$ Economic Thought, Foundational Problems of Mainstream Economics and the Alternative of Islamic Economics

This page is intentionally left blank 